\title{
Reflections on Justice in the Context of HIV/AIDS
}

\author{
by Elias K. Bongmba
}

The spread of the HIV and AIDS pandemic in the African context today calls for a critical reflection on the virtue of justice. I begin by describing in a broad manner recent perspectives on justice. I then examine the meaning of justice in the context of HIV AIDS, with a limited focus on religious healthcare, especially the Christian tradition that is a major partner in healthcare delivery in Africa. Justice for many is a national and global concern even though philosophers and theologians often examine justice within the confines of the nation state. Justice is a global issue because international protocols like the Universal Declaration of Human Rights and recent articulations of women's rights call for a rethinking of justice. The growing abuse of human rights today and the inability of many states to meet the basic needs of their citizens, especially in relation to food, water, and health point to the absence of justice. ${ }^{1}$ Charles Beitz argues that justice is a compelling idea for a cosmopolitan context because of growing economic interdependence and transnational politics. ${ }^{2}$

At the national level, the scope of justice includes individual and social units. It is a virtue grounded on the traits that people possess and exert; a view which John Rawls described as "the first virtue of social institutions". ${ }^{3}$ । understand virtues to be character traits as well as those dispositions which individuals develop to promote human wellbeing in each community. ${ }^{4}$ Philosophers and theologians have discussed justice as a social good that is related to the social contract because the idea and practice of justice requires a social context which in many cases is a settled political community where members seek the common good as they work out the relationship to one another and to the goals and vision of the community.

Aristotle described justice at the individual level as that characteristic which disposes an individual "to do just things, act justly, and wish just things". 5 He classified justice under two parts, general and the particular, which reflect what he describes as lawfulness and fairness. General Justice is lawfulness and deals with the sum of all virtues directed toward the good of another person. Particular justice refers to the right disposition towards good things such as security, money and honor in a political community. ${ }^{6}$ In further elaboration of particular justice, Aristotle defined it in terms of equality or fairness with respect to the common good that falls under the jurisdiction of the political community. He called general justice as that which is complete because it is based on laws and such justice is directed towards another per- 
son. Aristotle claimed: "justice alone of the virtues is thought to be the good of another." 7 On particular justice, Aristotle differentiated between distributive and commutative justice, indicating that distributive justice deals with the equal distribution of the common goods available to the political community. Distributive justice works on a proportional basis and what he called corrective justice promotes fairness and equilibrium in society. Commutative justice involves contracts and legal transactions.

Saint Thomas also described justice relationally; pointing that justice is the virtue that involves relationships between persons. Particular justice deals with one's relationship to another person and general or legal justice deals with communal matters. ${ }^{8}$ Overall, he argued that justice is that virtue which promotes fairness, as people see the common good. At the particular or individual level, compensatory justice deals with restitution and recompense. At the communal level, justice refers to the fair distribution of state resources. At both levels, communities strive to reach the good for members and seek ways of enabling members of the community to experience social justice.

Discussions of justice since 1971 has focused on the ground-breaking book, A Theory of Justice, by John Rawls in which he argued: "justice is the basic structure of society . . . the way in which the major social institutions distribute fundamental rights and duties and determine the division of advantages from social cooperation". ${ }^{9}$ Since members of a political community decide what is just through a process that involves public reasoning, debate, and deliberation by reasonable parties subjects, Rawls indicates that such a process allows participants to focus on seven primary goods distributed by the "political constitution and the principal economic and social arrangements" such as rights, liberties, selfrespect, power, opportunities, income, and wealth; goods which form a "thin theory of the good" and are crucial for well being of individuals and society. Principles of allocating these should be general, intuitively recognized, universal, public, offer preferences to conflicting claims, and must be final. Determining these, principles start at the "original position", a hypothetical situation that could serve as a prior position before human sociality where members of the political community acted as free agents, equal, rational, self-interested, and ignorant of their position, or their preferences and religious beliefs. This does not mean that start with a blank slate because they have some general information and come with conflicting claims. Rawls argues that members could develop an overlapping consensus in a competing liberal context where they share values such as democracy and similar visions of the political economy. A broad consensus could ensure that "all social values-liberty and opportunity, income and wealth and the bases of selfrespect-are to be distributed equally unless an unequal distribution of any, or all, of these values is to everyone's advantage". ${ }^{10}$ Justice for Rawls is undeniably part of a liberal social system 
where the idea of equality is central to growth of individuals and members of the political community.

Some scholars who have responded to Rawls' position point out that Rawls theory presupposes and privileges western democratic liberalism and a capitalist society, and does not adequately address human rights since his theory emphasizes the social dimension of justice. Others argue that Rawls's theory does not consider gender and other social inequalities, and the notion that there could be some hypothetical situation devoid of preconceptions where the principles of justice could be initiated seems unrealistic. ${ }^{11}$ Feminist scholars contest the view that justice can be a non-contextual dispassionate construction. Seyla Benhabib has argued that an ethic of justice must consider not only the concrete history of people, but also the "identity and affective-emotional constitution" of others in the community. ${ }^{12}$ Kathryn Tanner has pointed out, "A just society is not simply a society that allows people to go their own way, a just society is one that actively cares for its members by providing the 'institutional conditions that enable people to meet their needs and express their desires'". ${ }^{13}$ Carol Gilligan in her book, In a Different Voice, has argued for the notion of care as part of understanding justice. ${ }^{14}$ Gilligan has argued women develop differently than men because their moral thinking is connected to an ethics of care. Concern for the good of others is not grounded primarily on principles and rules but caring as a virtue, which recognizes inter-human connectedness and one's views of justice also depend on human connectivity, and care.

Rawls' account remains significant because he argues: "justice as fairness assigns a certain primacy to the social", a view that does not ignore individual human rights. ${ }^{15}$ In other words what Rawls describes, as "the profoundly social nature of human relationships" does not necessarily dismiss individuality. ${ }^{16}$ The social context provides a broad environment for cultivating certain virtues, and human capacities for moral reasoning. In principle, many expect social structures and institutions to promote and be the arbiter of justice in different ways. For example, legal systems provide mechanisms for adjudicating disputes, contracts, and safeguards property rights which are connected to social harmony and hence the cultivation of justice in society. Social structures also provide a basis for thinking of individual and family life. These structures are necessary for people to think of their rights and responsibilities to others. Sociality offers a basis for equality and freedom for members to conceptualize justice, fairness, and develop the rational capacities for debating and articulating the principles of justice. ${ }^{17}$ There is no doubt that Rawls' veil of ignorance which is integral to his notion of the original position is an ideal situation where bound by a social contract, members of a political community could arrive at fair principles; which given freedom and equality, would facilitate the promotion of a just society. ${ }^{18}$

Even if one were to grant as I do that Rawls does not rule out individual- 
ity, the idealism embedded in his theory remains problematic because social groups have discrepancies emerging from or grounded on race, gender, ethnic origin, and religion. In addition to these, problematic issues, in some countries around the world, the difficulty of attaining what Rawls, proposed is constantly being undermined by political corruption. To overcome this deficiency Rawls redefined the original position, arguing: "among the essential features of this situation is that no one knows his place in society, his class position or social status, nor does anyone know his fortune in the distribution of natural assets and abilities, his intelligence, strength and the like. I shall even assume that the parties do not know their conceptions of the good or their special psychological propensities. The principles of justice are chosen behind a veil of ignorance." 19 This is hardly the case in most societies because people have more information about the behavior of others and their own than the theory allows.

The proposals of Rawls reflect arguments that could take place in an open society or what some would describe as a liberal political community. In the late $20^{\text {th }}$ century, it became clear that not everyone shares the same enthusiasm about the virtues of liberalism. For example, Philosopher Alasdair Maclntyre who himself has a passionate interest in virtues and justice has decried the absence of virtue in the modern world, a situation which has made it difficult for moderns to have a common consensus on justice. ${ }^{20}$ In Whose Justice? Which Rationality? Maclntyre, has argued that the liberal society lacks a coherent account of justice because the liberal society is grounded on the misguided Enlightenment project out of which has come greater emphasis on individualism and a doctrine of rights. ${ }^{21} \mathrm{Ma}$ clntyre prefers the articulation of justice found in the Thomistic synthesis of the Augustinian and Aristotelian traditions because in Maclntyre's view, modern approaches to justice are grounded on a rights approach and ignores the social and intellectual traditions that have provided humankind with ideas and practices of justice.

Many scholars recognize Maclntyre's passion for the virtues and justice but have misgivings about his dismissal of liberalism. Hence, one could argue that Macintyre assumes that there was always so kind of a coherent narrative on justice, which moderns lack because of their commitment to Enlightenment liberalism. However, in fairness to Maclntyre, one should point out that Maclntyre discusses the different positions on justice that existed in the Greek polis, giving rise to accounts of justice that were grounded in practical reasoning to arrive at a consensus on justice (dikaiosune), or righteousness. ${ }^{22}$ Maclntyre argues:

The name the Greeks gave to this form of activity was 'politics', and the polis was the institution whose concern was, not with this or that particular good, but with human good as such, and not with desert or achievement in respect of particular practices but with desert and achievement as such. The constitution of each particular polis could therefore be understood as the expression of a set of principles about 




how goods are to be ordered into a way of life. ${ }^{23}$

In rejecting liberalism and dismissing the Enlightenment project, Maclntyre also fails to appreciate the view that:

A (person) becomes fully human only when, instead of remaining subject to given needs and desires, he (she) shapes his (her) conduct by a law he gives himself, and morality is not only one form of such self-legislation, but also a necessary one for all humanity. ${ }^{24}$

The political ideals of a liberal state such as "liberty, equality, and fraternity" have contributed significantly to freedoms, human rights, and the search for a consensus and it would be a mistake to dismiss liberalism because of a past lofty tradition. ${ }^{25}$ Second, even if one were to endorse Maclntyre's argu- ment, it would be good to remember that even in the Aristotelian society, which Maclntyre discusses approvingly, individual agency was not completely lost because people excelled in different roles first as individuals and they brought those roles together to make the community function. Third, one would agree with Rawls that the liberal tradition, despite its limitations, offers a better political space and climate to address moral issues, especially justice than Maclntyre's preferred religiously influenced traditions.

Amartya Sen has argued that RawIs's justice as fairness articulates a transcendental perspective, focuses on the nature of a just society in contrast to a comparative approach to justice and fairness which offers alternative arrangements and makes room for the 
view that some approaches are more or less just than others. ${ }^{26}$ Sen claims that the comparative approach is compelling because it invites a consideration of social policies that might eliminate hunger and illiteracy and contribute to justice, but the implementation of such policies might violate the transcendental requirements of justice that include "equal liberties and distributional equity." 27 The comparative approach might be incomplete but thinking from a comparative perspective could highlight injustice at a time when many are destitute in a world of prosperity. Such an approach could also highlight practices that encourage the subjugation of women. Sen emphasizes that even where people have a specified view of justice, shared beliefs could provide partial ranking; making "evaluative incompleteness" relative to a theory of justice. ${ }^{28}$ Finally, Sen argues that institutional requirements of the Rawlsian approach would be difficult to meet in the context of global justice, even with Rawls new starting point which emphasizes negotiation with different peoples and the giving of reasonable help to decent societies that may not be just. ${ }^{29}$ Sen argues that what emerges is a silence that inhibits public reasoning about justice in the manner that Rawls has presented in his transcendental perspective. Rawls's view about a common starting point ignores the possibility of impartial arbitration, shared beliefs, and prejudices that might offer people an opportunity to examine issues from the perspective of other informed people who do not belong to the same society. ${ }^{30}$

\section{Justice and Public Health at a time of HIV and AIDS}

One area where justice is a major issue is health care. In many parts of the world, there are contentious debates about the availability of and accessibility of health care for all the members of the political community. The debates and contestations on health and healthcare tend to focus on public health, where the role of the state is central in the quest for justice ${ }^{31}$. Consideration of social justice and fairness in the context of public health is crucial in the African context and one could argue that it does not matter whether social justice is seen in the light of what ethicist call beneficence or not. This is the case because many now think that the state plays a crucial role in promoting and making health care available and affordable as a major political responsibility. ${ }^{32}$ Many countries provide healthcare through government programs and the state establishes health care institutions and sets the rule that govern healthcare from the training of health care workers to acceptable standards for drugs.

The view that health care brings up the question of justice has gained traction in the debate in recent years to the extent that health has become a matter of rights which can be studied in light of the United Nations Declaration of Human Rights in 1948. Although that declaration was adopted when almost all African countries were still colonies, nearly all African countries joined the United Nations and accepted the declaration on human rights and moved 
in the late twentieth Century to adopt the African Charter of rights as well as joined global movements promoting women and children's rights.

The dominant role the state plays in healthcare does not rule out private healthcare providers in Africa, especially, religious communities. Even in the United States, many of the major hospitals are privately owned, have religious background or are incorporated businesses that do not receive any support from the State. In Africa, individuals and religious communities offer health care and run their own facilities. Studies carried out by scholars from South Africa and the United Stated through the African Religious Health Assets Program (ARHAP) has demonstrated that in many parts of Africa, religious institutions provide between 30 and 70 percent of the healthcare needs of some countries. ${ }^{33}$ Globally, healthcare is a concern of organizations like the World Health Organization that works with over 190 nations. Other agencies of the United Nations are also involved in health care projects. The most well known example in the last three decades is the Joint United Nations Program to combat HIV AIDS (UNAIDS) that was formed to bring together information and strategies of preventing the spread of HIV AIDS and coordinate treatment around the world.

There is no uniformed understanding of what good health is, and there is no single approach that guarantees wellbeing. Instead, the standards, procedures, and moral perspectives that serve as a guide for public health vary and are negotiable. What constitutes the goals of public health varies, but one can generalize from the activities that are carried out and indicate that public health is the means by which states and other private stakeholders promote health as a public good. Public health is not restricted to medicalization, but includes preventive health care. Prevention methods and programs vary, but they range from the many attempts to eliminate injury, the taking of prophylaxis, and vaccination campaigns. Where the state encourages good prevention methods, the cost of healthcare is greatly reduced and members of the community live healthier lifestyle. Public health remains an important part of government responsibility even though there are many private agencies and faith based organizations that do health work and are important stake holders in the healthcare industry of several countries.

The view that healthcare demands justice is also clear from the fact that for many people the cost of healthcare is prohibitive. In many communities, it is the state that has the capacity and the resources necessary to meet the demands of public healthcare. Even where other organizations are able to provide public health care in an efficient manner, the government still plays an important regulatory role that could affect everything from drug acquisition to the type of drugs that are safe to use or set the basic standards needed for people to qualify as healthcare workers. Standards established by states and the careful use of regulatory systems to supervise health care offer opportunities to gauge the state of justice in health- 
care. Many of the debates on healthcare are grounded in the quest for fairness, equal access, and availability of quality drugs. ${ }^{34}$ Most of the debates on healthcare focus on justice and several scholars in the twentieth century have examined justice through an examination of ethical issues through several academic programs such as bioethics, biomedical ethics, medical ethics, medical humanities. Finally, although no single approach defines or indicates the scope of public health, it is also the case that the goals and programs carried out in the name of public health often reflect the desire to achieve quantity as well as quality of care for members of the political community. For instance in the 1978 Alma Ata declaration, the World Health Organization member states pledged that they would achieve health for all by the year 2000.

The search for what is fair in public health remains a central issue around the world. In addition to the cost of healthcare, many questions are unresolved such as the scope of public health itself. Is public health a common good? If it is defined as a common good, should everyone have access or if all have access to good medical care should the quality of that healthcare be the same for everyone in the political community? Is it possible then that the state can provide equal health care to all members of its political community? In other words, to what extend is healthcare public when it includes disparities in terms of access and quality of care? The provision of basic care to all members of the political commu- nity could go a long way in preventing future cost or overwhelming the healthcare system. That is why some have argued that a key way to achieve justice in publish health is to distribute the resources or burdens of healthcare among all the members of the political community.

If justice is an important virtue and if achieving it in the political community, its success depends on the political will of the community. The question is; what are the things that impede the attainment of justice especially in the area of healthcare in the African context. The issues in healthcare remain lack of accessibility, and lack of resources to pay for the medical needs of many people. This does not mean that Africa is devoid of health institutions; what is implied here is the view that healthcare is inadequate and always there is little quality healthcare for the majority of people in the community. Often decisions about health care are made by government bureaucrats who do not often consult with all the stakeholders. This is a region where long term militarization has depleted the economies and the long economic decline, which started in the 1970s, has not yet ended. Additionally questions remain about poor governance, and political corruption that has continued on a massive scale. The alleged scale of corruption has taken money that could be used to address health issues out of the countries in Africa. If one takes a look at the allegations and in some cases court papers filed in Western countries to recover what is believed to be illegally gotten wealth by politicians 
and members of their families, it immediately becomes clear that such a diversion of public funds at a time when the region is hardest hit with a pandemic that is not letting down and ongoing struggle with illnesses such as malaria, all actions that divert money away from important programs like healthcare into personal bank accounts of the political elites constitutes injustice.

The literature on political corruption in Africa is full of accusations about corruption. For example, Newstime Africa, reported on October 29, 2011 that the United Sates Justice Department had finally made a move and seized a mansion in Malibu California, Gulfstream jet, Michael Jackson memorabilia that belonged to Teodoro Nguema Obiang Mangue, the son of President Teodoro Obiang Nguema Mbasogo of Equatorial Guinea. ${ }^{35}$ The US Justice Department also filed suit in a court in Los Angeles, alleging that Teodoro Obiang Nguema Mange who is also Minister of Agriculture in his father's government had plundered billions of dollars from his country "to buy flashy cars, racing boats, a $\$ 38$ million Gulfstream jet and the $\$ 30$ million Malibu mansion." Published reports indicate that the son of the President who is accused in the court papers has reportedly spent millions of dollars in a lavish playboy lifestyle in Europe. Other sources such as Global Witness alleged that banks such as Wachovia, Bank of America, and UBS bank might have done nothing to prevent Teodoro Obiang Nguema Mangue to transfer as much as $\$ 100$ million into the United States to pay for these luxury items. Such alleged swindling of funds comes from a country, which until the discovery of oil, depended on foreign aid.

In Europe, the Mail Online, reported that several properties and expensive cars had been seized from the home of an African dictator in Paris. "The vehicles, which included two Bugatti Veyrons, a Ferrari 599 GTO and a Maserati MC12 are all registered to Teodoro Obiang Nguema, the president of Equatorial Guinea". At one of his residence on Avenue Foch, which is close to Arc de Triumphe, police also seized several luxury cars belonging to the Equatorial Guinean President. The vehicles "included an Aston Martin V8 600lm, Rolls-Royce Drophead Coupe, a Porsche Carrera GT, and a Ferrari Enzo, as well as various Bentleys". Newstime Africa also reported that the Obiang Nruema's are not the only politicians in Africa because the current President of Gabon, Ali Bongo reportedly has 39 properties and Denis Sassou-Ngeusso of the Republic of Congo is alleged to have about 16 properties.

One of the greatest health challenges in Africa today is the HIV and AIDS pandemic, an illness that is individual as it is social. How can one talk of justice in such context? Broadly stated, justice in the context of HIV and AIDS involves carrying out the obligations of human relationships at the individual and communal levels. ${ }^{36}$ People relate to others as family, friends, professional colleagues, members of a religious community, different kinds of proximal relationships, or political configurations structured by constitutions and institutions. Globalization has created new 
forms of proximities and extended the scope of obligations, opening a creative space for understanding justice which J. B. Schneewind calls "the habit of following right reason with respect to the rights of others". ${ }^{37}$ Therefore, minimally, relationships imply a reasonable recognition of the rights of others for wellbeing. These rights include the right to be treated as equal partners of members of the community who deserve liberties, self-respect, opportunities to participate in the economic and political life of the community. Justice in this context involves activities that would enable members of the political community experience the common good. Justice then is civic praxis.

Individuals and members of the political community need a new dedication to the idea of a civic praxis rooted in human values. Maclntyre argued: "The underlying concept of goodness (which) has as its focus a conception of perfected excellence in a type of activity specific to a particular type of person. A virtue is a quality of a character necessary for the achievement of such a good. And justice is the key virtue because both the in the psuche and the polis only justice can provide the order which enables the other virtues to do their work". ${ }^{38}$ The polis was not an equal space as we understand equality today, but what I stress here is the idea that members of a community can and should cultivate virtues, among which justice is central, because it enables the other virtues to work.

In context of HIV/AIDS, a civic agenda that could promote justice and fairness implies a number of practices that could help clarify a rational perspective of justice. First, members of the political community ought to understand the HIV virus, its spread, replication, and the illnesses that result from a weakened immune system. Thirty years after the discovery of the virus, religious and state leaders still have an obligation to educate people about the virus so that they can make informed decisions on the risks they face. Arriving at what to teach calls for constant dialogue by all interested parties. Second, understanding the situation calls for each person to assume responsibility in creating safe environments, where the most vulnerable people to HIV infections, women and children will feel protected and take responsibilities for their own sexuality. In addition to education on the virus, a sustained civic practice requires that the state provide resources to fight HIV and AIDS and depend mostly on non-governmental organizations (NGOs) and faith-based organizations (FBOs).

Finally, promoting justice involves civic practices that involve advocacy for those living with the virus and those who are affected by it in different ways; either as caregivers, or members of the family who have experienced a decline in health and living standards because they care for someone living with HIV and AIDS. Civic activism and advocacy could change public and state obligations on HIV and AIDS. This has happened in several African countries, especially South Africa where members of the Gay, Lesbian, bisexual and transgender community have shaped the debate on HIV and AIDS and ac- 
cess to life saving drugs. Civic activism demonstrates that health care is a social good for all members of the community. In several African countries politicians often have good health care at the expense of other members of the society. Religious communities and leaders could shape the debate on access to healthcare as a matter of social justice in such contexts. Thomas Ogletree has argued: "When some fare well and attain much, it is almost always at the expense of others, indeed, not infrequently by virtue of the domination and exploitation of those others. Excellence achieved at such a price is morally dubious at best. It takes on a morally negative cast insofar as it is a function of structural forms of social injustice". 39

Dialogue and advocacy could be grounded on concepts and principles that have high purchase in the community. African scholars have appealed to Ubuntu as a concept that stresses a humane practice of relating, sharing, expressing hospitality, and enabling others to achieve the good in society. Ubuntu also promotes values of love, support, and respect for others in society. The concept is derived in the Southern African contacts from the Isizulu expression, "umuntu ngumuntu ngabantu," which means "a person is a person through persons". This definition is compelling and one could reject articulations of Ubuntu that compare it to the Cartesian cogito as several African scholars have done. Additionally, ubuntu is not merely a communitarian ethic that stresses the community at the expense of the individual. The concept includes both an individualist ethos and well as communitarian principles. It highlights individual subjectivity and the values shared by members of a community and as such offers an important conceptual tool for establishing intersubjectivity and prioritizing the rights of persons and communities. Finally, it is not correct to argue as Emmanuel C. Eze has claimed that ubuntu neglects reason, because reason in ubuntu prioritizes the person and community. ${ }^{40}$

The World Health Organization demonstrates that inequality exists in healthcare. ${ }^{41}$ The claims of justice invite a stand against inequality in the political community. ${ }^{42}$ The inequality that exists in African countries is measurable and there are remedies that could be applied to create a more just situation. Although religious communities carry a large share of healthcare in Africa, the nation state can ensure justice by setting healthcare policies that will promote the common good. Such policies should privilege equal access, affordability, and sustainability.

In addition to civic practices, one could approach claims of justice by critically examining policies of the state in light of primary healthcare which is seen by many health experts as a major preventative measure and tool that could reduce hospital based care. Primary healthcare does not need expensive healthcare facilities but involves interventions which are part of the social projects of every state such as good sanitation, safe and affordable drinking water, good communication infrastructure which would allow people have access to care in a hospital or dispensary should that become neces- 
sary, and adequate women's care that includes family planning. To be fair to states, some governments in Africa have established a hospital or two in each district. However, many of those hospitals are poorly staffed and have no functioning pharmacies. These situations have compromised health care, especially for the poor who do not have access to expensive care and drugs.

Finally, the Christian tradition is involved in healthcare in several African countries. Doing good and searching for justice in healthcare is a long tradition in the Christian church. The search for justice in the Christian tradition is often grounded in the work of the Hebrew Bible proposition that human beings carry the image of God. This is a religious and partisan view that cannot be imposed on other partners in dialogue on justice, but it is important because it underscores that value of a common humanity, which also recognizes differences of opinion about the nature of the common good, and ways of achieving the good. ${ }^{43}$ The idea of the image of God in humanity also emphasizes the people more than desserts or reciprocity. All people in any given social context then deserve justice in a context of competing views of the good without necessarily imposing a transcendental position by claiming that God has ordered the idea of justice? While the symbols used by the Hebrew prophets may generate a discussion about justice, religious communities have an obligation to establish open dialogue with other communities on achieving the common good and justice. People share a common humanity, basic desires, needs, and could collaborate to meet those needs more effectively.

\begin{abstract}
Notes
1 See Martin Wight, "Why is there no International Theory?" in Herbert Butterfield and Martin Wight (eds.), Diplomatic Investigations: Essays in the theory of International Politics (London: George Allen and Unwin, 1966), p. 20; Brian Barry, Political Argument: A Reissue with a New Introduction (New York: Wheatsheaf Harvester, 1990), p. Lxxiv. I have also benefited from recent discussions of justice. See: Michael Slote, "Justice as a Virtue", The Stanford Encyclopedia of Philosophy (Fall 2010 Edition), Edward N. Zalta(ed.), URL = http://plato.stanford.edu/ archives/fall2010/entries/justice-virtue/; Samuel Freeman, "Original Position",The Stanford Encyclopedia of Philosophy (Spring 2012 Edition), Edward N. Zalta(ed.), URL = http://plato. stanford.edu/archives/spr2012/entries/original-position/; Julian Lamont, and Christi Favor, "Distributive Justice",The Stanford Encyclopedia of Philosophy (Fall 2008 Edition), Edward N. Zalta(ed.), URL = <http://plato.stanford.edu/archives/fall2008/entries/justice-distributive/>

2 Charles R. Beitz. "Cosmopolitanism and Global Justice." The Journal of Ethics, Vol. 9 no. 1 and 2 (2005): 11-27; see also Michael Blake, "International Justice", The Stanford Encyclopedia of Philosophy (Winter 2008 Edition), Edward N. Zalta(ed.), URL = <http://plato.stanford. edu/archives/win2008/entries/international-justice/>.

3 John Rawls, A Theory of Justice. (Cambridge, MA. Harvard University Press) 1971, p. 3.

4 eenan has argued: "virtues are traditional heuristic guides that collectively aim for the right realization of human identity ... The historical dynamism of the virtues applies ... to the anthropological vision of human identity." Keenan, 2000, p. 74. Keenan has explored cardinal virtues and emphasized justice, prudence, fortitude, and temperance. He has replaced
\end{abstract}


temperance with fidelity and self-care, Keenan 1995; See also, Elias K. Bongmba, Facing a Pandemic, The African Church and Crisis of AIDS. (Waco: Baylor University Press, 2007).

5 Aristotle, The Nicomachean Ethics, 1129a3-11.

6 1130a32-b5.

7 1130a3-5

8 Saint Thomas Aquinas, Summa Theologiae, Thomas Gilby ed. 1975, p. 31.

9 John Rawls, A Theory of Justice, p. 7.

10 Rawls, 1971, p. 62.

11 See for instance critiques by John Langan

12 Seyla Benhabib, Situating the Self: Gender, Community and Postmodernisn in Contemporary Ethics. (New York: Routledge, 1992), p. 158-70.

13 Kathryn Tanner, "The Care that Does Justice: Recent Writings in Feminist Ethics and Theology,' Journal of Religious Ethics (2001): 171-191.

14 Carol Gilligan, In a Different Voice: Psychological Theory and Women's Development (Cambridge: Harvard University Press, 1982). See also Kathryn Tanner has argued that feminists scholars have rejected the "dualism of moral orientation in public and private spheres...by a process of mutual critique, so that, for example, the family becomes a place of justice and public life an arena dedicated to nurture." Kathryn Tanner, (2001), p. 174.

15 John Rawls, CP, 339.

16 John Rawls, Political Liberalism. (New York: Columbia University Press, 1993) p. 259

17 John Rawls, p. viii

18 John Rawls, p. 120.

19 John Rawls, p. 12

20 Alasdair Maclntyre, After Virtue, (Notre Dame: University of Notre Dame Press, 1988); See also his Whose Justice? Whose Rationality? (Notre Dame, IN: University of Notre Dame Press, 1988).

21 Maclntyre, After Virtue p. 111

22 Whose Justice p. 33.

23 Whose Justice p. 34

24 Lamore, Charles. Patterns of Moral Complexity (London: Cambridge University Press, 1987) p. 31

25 Richard Bernstein"Nietzsche of Aristotle? in Philosophical_Profiles (Philadelphia: University of Pennsylvania Press, 1986) p.140

26 Amartya Sen, "What do We Want from a Theory of Justice?" Presentation at Rice University, Feb. 2006, p. 3.

27 Sen, p. 4. See also Amartya Sen, Collective Choice and Social Welfare, (San Francisco: Holden-Day, 1971).

28 See Amartya Sen and W. G. Runciman, "Games, Justice and the General Will, in Mind, 74, (September, 1965); See also Thomas Scanlon, What we Owe to Each Other, (Cambridge, MA: Harvard University Press, 1998), p. 5; Thomas Scanlon, "Contractualism and Utilitarianism" in Amartya Sen and Bernard Williams, eds., Utilitarianism and Beyond, (Cambridge: Cambridge University Press, 1982); these references are taken from Sen, 2006, p. 18.

29 John Rawls, The Law of Peoples, Cambridge, MA: Harvard University Press, 1999). 
30 Amartya Sen, "Open and Closed Impartiality," Journal of Philosophy, 99 (September, 2002)

31 Gopal, Sreenivasan, "Justice, Inequality, and Health",The Stanford Encyclopedia of Philosophy (Spring 2009 Edition), Edward N. Zalta(ed.), URL = <http://plato.stanford.edu/archives/ spr2009/entries/justice-inequality-health/>.

32 Powers and Faden 2006, Institute of Medicine's Committee for the Study of the Future of Public Health 1988; Thomas 2002; Nuffield Council on Bioethics 2007.

33 See ARHAP Report

34 Childress et al, 2002.

35 http://www.newstimeafrica.com/archives/23046. This story was first reported by the Wall Street Journal.

36 Karen Lebacqz, "Justice," in Christian Ethics: An Introduction, ed. Bernard Hoose, (Collegeville, MN: The Liturgical Press, 1998, p. 169.

37 J. B. Schneewind, "The Misfortunes of Virtue." In Virtue Ethics, edited by Roger Crisp and Michael Slote, 178-200, (Oxford: Oxford University Press, 1997), 183.

38 Maclntyre, Whose Justice, p. 74.

39 Thomas W. Ogletree, The Use of the Bible in Christian Ethics, (Philadelphia: Fortress Press, 1983), p. 32.

40 Emmanuel Chukwudi Eze, On Reason: Rationality in a World of Cultural Conflict and Racism (Durham: Duke University Press, 2008). See my response in Elias K. Bongmba. "Beyond Reason to Interdisciplinary Dialogue on Morality and Politics in Africa: Comments on E.C. Eze's 'Between History and the Gods: Reason, Morality, and Politics in Today's Africa'." Africa Today, Vol. 55 Number 2 (2000): 98-104.

41 See The world Health Organization on Social Determinants of Health at: http://www. who.int/social_determinants/en/ accessed March 15, 2012. For a general philosophical discussion of inequality see Larry Temkin, Inequality. Oxford: Oxford University Press, 1993.

42 A. Culyer and A. Wagstaff. "Equity and equality in health and health care," Journal of Health Economics12: (1993):431-57.

43 Charles Curran, Catholic Social Teaching, 1891-Present: A Historical, Theological and Ethical Analysis (Washington DC: Georgetown University Press, 2000), 189. 